\title{
Effects of degradable films with different degradation cycles on soil temperature, moisture and maize yield
}

\author{
Lixia Shen ${ }^{1 *}$, Yumeng Zhang ${ }^{2}$, Yinchao Lan ${ }^{1}$, Ruofan $\mathrm{Li}^{1}$ \\ (1. College of Water Conservancy and Engineering, Taiyuan University of Technology, Taiyuan 030024, China; \\ 2. College of Urban and Environmental Science, Northwestern University, Xi'an 710127, China)
}

\begin{abstract}
Photo biodegradable film is an ideal degradable mulch film with synergistic effect of photo-degradability and biodegradability. To examine the covering effects of different films, maize was cultivated in the field with three kinds of degradable films (DF) mulching which had different degradation cycles (DF No. 1, No. 2 and No. 3), with common plastic film mulching and no filming mulching (open ground) as comparison. The degradation rates and degrees of degradable films were examined, and the effects of different films on soil temperature, soil moisture, maize yield and relevant characteristics in each treatment were analyzed. The results indicated that the degradable films had good degradability, and the weight loss rate in $100 \mathrm{~d}$ for DF No.1, No.2, and No.3 were $22.31 \%, 19.46 \%$, and $15.63 \%$, which were 4.16, 3.63, and 2.92 times of the plastic film, respectively. In the early period of maize growth, the degradable films had good warming effects on soil, which were similar with the plastic film. The effect of DF No.2 on soil water conservation was slightly better than that of DF No.1 or No.3, similar with that of the plastic film. The soil water contents in $0-140 \mathrm{~cm}$ depths were significantly higher for DF No.2 than that for the open ground $(p<0.05)$. The degradable films could significantly promote the ear development of maize, improve the ear characteristics, shorten the bald tip, and increase kernel number per plant (KNP) and 1000-kernel weight (TKW). The grain yields (GYs) for DF No.2, No.1, and No.3 were significantly improved, with 35.15\%, 31.35\%, and 30.07\% higher than that the open ground respectively $(p<0.05)$. With no significant difference between DF and the plastic film, the GY was increased more for DF No.2 than that for DF No.1 and No.3. The degradable films fulfilled successfully all the functions of the plastic film, thus they were recommended as viable option to the plastic film due to their good degradability.

Keywords: degradable film, photo biodegradable film, soil temperature, soil moisture, maize, yield

DOI: $10.25165 /$ j.ijabe.20191203.4065
\end{abstract}

Citation: Shen L X, Zhang Y M, Lan Y C, Li R F. Effects of degradable films with different degradation cycles on soil temperature, moisture and maize yield. Int J Agric \& Biol Eng, 2019; 12(3): 36-44.

\section{Introduction}

Film mulching has developed rapidly and has been widely used in China since its introduction in 1978, and its benefits of earlier harvest can be summarized as a result of increasing soil temperature, enhancing the efficiency of fertilizers and water levels, improving total soil porosity, reducing soil erosion, and increasing crop yield and quality ${ }^{[1-5]}$. However, the films used in China were mostly the conventional plastic films made from polyethylene, which cannot be naturally biodegraded in the field ${ }^{[6-8]}$. The main negative consequence of using plastics in agriculture is related to the plastic wastes handling and the associated environmental impact. Only a small fraction of the plastic films is currently recycled due to the expense and time required for recycling, and a large portion of plastic films is left on the field or burnt uncontrollably by the farmers, emitting harmful substances with the associated negative consequences to the environment ${ }^{[9-11]}$. Accumulated plastic film residues in the soil deteriorate the soil

Received date: $2017-12-22 \quad$ Accepted date: 2019-03-25

Biographies: Yumeng Zhang, Master candidate, research interests: efficient utilization of water and fertilizer, Email: 491025435@qq.com; Yinchao Lan, Master, research interests: efficient utilization of water and fertilizer, Email: lanyinchaoqq@163.com; Ruofan Li, PhD candidate, research interests: efficient utilization of water and fertilizer, Email: ruofanpiaoxue@163.com.

*Corresponding author: Lixia Shen, $\mathrm{PhD}$, Professor, research interests: efficient utilization of water and fertilizer. College of Water Resource Science and Engineering, Taiyuan University of Technology, Taiyuan 030024, China. Tel: +86-13623608332, Email: shenlixia919@sohu.com. structure, inhibit crop roots from absorbing water and nutrients, reduce crop yields, and limit the sustainable development of agriculture $^{[12-14]}$.

In recent years, the alternative materials that can degrade or come from renewable sources such as photo-degradable, biodegradable, oxo-degradable or oxo-biodegradable films, paper mulches, bast fiber mulches or crop residues are found to overcome these environmental problems, and many experiments have been carried out to examine the covering effect of different types of degradable films in the field ${ }^{[15-18]}$. The main causes for degradation of degradable films during their lifetime are photo-degradation (a degradation process caused by the absorption of photons, particularly those wavelengths found in sunlight, such as infrared radiation, visible light, and ultraviolet light) and biodegradation (a degradation process resulting from the action of naturally occurring microorganisms such as bacteria, fungi, and algae, degrading into products such as carbon dioxide or methane and water). With synergistic effect of photo-degradability and biodegradability, the photo biodegradable film is an ideal degradable mulch film, of which both the buried and ground part can be thoroughly degraded as the ground part can be photo-degraded and the buried part can be biodegraded. However, the degradation of the photo biodegradable film is more difficult to be controlled due to the influence of the regional climate, natural conditions and crop varieties. Previous studies were mainly focused on comparing the covering effects of different types of degradable films but not on different degradation cycles. The objectives of this study were to (1) examine the degradation rates 
and degrees of degradable films with different degradation cycles, and (2) assess the effects of degradable films with different degradation cycles on soil temperature and moisture, as well as the effects on maize grain yield and its components.

\section{Materials and methods}

\subsection{Experimental details}

Field experiment was carried out in Hecun Village, Lingjingdian Township, Yangqu County, Shanxi Province, China $\left(38^{\circ} 05^{\prime} \mathrm{N}, 112^{\circ} 65^{\prime} \mathrm{E}\right)$, during the maize-growing season from April to October in 2013. The test site was located in a typical semi-arid region with continental monsoon climate with annual average precipitation of $434.7 \mathrm{~mm}$, average annual evaporation of $328.9 \mathrm{~mm}$, and annual average temperature of $6.86^{\circ} \mathrm{C}$. Average frost free period was $120 \mathrm{~d}$ with the early frost in mid-September and the last frost in mid-May. Soil analysis $(0-20 \mathrm{~cm}$ and $20-$ $40 \mathrm{~cm}$ ) indicated organic matter of $7.66 \mathrm{~g} / \mathrm{kg}$ and $7.81 \mathrm{~g} / \mathrm{kg}$, total N of $0.67 \mathrm{~g} / \mathrm{kg}$ and $0.64 \mathrm{~g} / \mathrm{kg}$, hydrolyzable $\mathrm{N}$ of $53.33 \mathrm{~g} / \mathrm{kg}$ and $60.55 \mathrm{~g} / \mathrm{kg}$, available phosphorus of $4.68 \mathrm{mg} / \mathrm{kg}$ and $3.98 \mathrm{mg} / \mathrm{kg}$, rapidly available potassium of $81.67 \mathrm{mg} / \mathrm{kg}$ and $85.02 \mathrm{mg} / \mathrm{kg}$, respectively.

\subsection{Treatments and experimental design}

The experimental plastic film was produced by The Third Plastic Factory in Ji'nan, Shandong Province, China, with a film width of $80 \mathrm{~cm}$ and a film thickness of $0.005 \mathrm{~mm}$. Three kinds of degradable films (DF) with different degradation cycles (DF No. 1, No. 2 and No. 3) were photo-biodegradable films produced by Tianjian Polymer Materials Limited Company, Hebei Province, China, with a film width of $80 \mathrm{~cm}$ and a film thickness of $0.005 \mathrm{~mm}$, too. The tested maize variety was Xianyu 335, widely cultivated in Shanxi Province, China.

The experiment set 5 treatments including one plastic film, 3 kinds of degradable films and one open ground control. Each treatment has 3 repetitions and a total of 15 plots were arranged in random area (Figure 1). The plot area was $42 \mathrm{~m}^{2}(6 \mathrm{~m} \times 7 \mathrm{~m})$, with maize row spacing of $60 \mathrm{~cm}$, plant spacing of $25 \mathrm{~cm}$, and theoretical density of 60000 plants $/ \mathrm{hm}^{2}$.The film mulching plots were firstly covered by the film and then artificial sowing was carried out. Maize was sown in April 26th and harvest in October 1st. Field management was the same as the local general field.

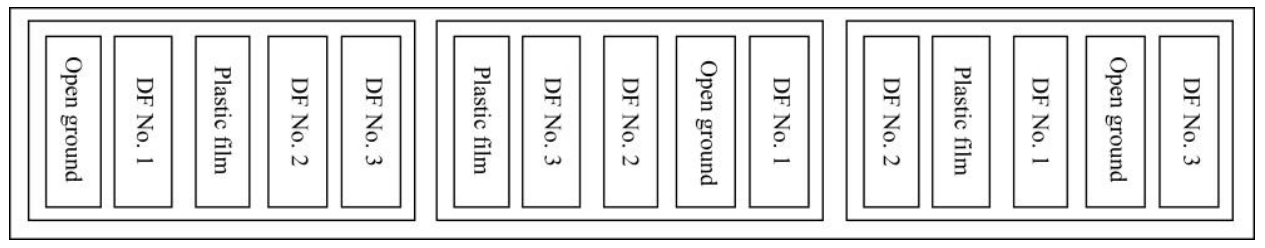

Figure 1 Experimental design

\subsection{Measurements}

\subsubsection{Degradation rate and degree}

Film condition was observed once every $10 \mathrm{~d}$ after film mulching. The grading standards were as follows: Level 0: no cracks (including wind and man-made damage); Level 1: cracks began to appear (induction period); Level 2: small cracks in the 25\% film; Level 3: 2-2.5 cm cracks appeared; Level 4: uniform network cracks appeared, film thinning, and no large film exists; Level 5: the film was broken into fragments below $4 \mathrm{~cm} \times 4 \mathrm{~cm}$.

Before film mulching, the $1 \mathrm{~m}$ film segments of 3 kinds of DF and one PF were taken randomly, weighed and recorded as the original weight $\left(W_{o}\right)$ of $1 \mathrm{~m}$ film segment. When film mulching and sowing in the main plot, the film segments were laid in the field, and covered with transparent gauze nets, but no sowing was carried out. At $100 \mathrm{~d}$ after mulching, the gauze nets were removed and the fragments of $4 \times 4 \mathrm{~cm}^{2}$ above were selected, washed, dried by airing, weighed separately, and recorded as the present weight $\left(W_{p}\right)$ of $1 \mathrm{~m}$ film segment. The weight loss rate (WLR) in $100 \mathrm{~d}$ was calculated as follows:

$$
W L R \text { in } 100 \mathrm{~d}=\frac{W_{o}-W_{p}}{W_{o}} \times 100 \%
$$

where, $W_{o}$ is the original weight of $1 \mathrm{~m}$ film $100 \mathrm{~d}$ ago, and $W_{p}$ is the present weight of $1 \mathrm{~m}$ film in $100 \mathrm{~d}$.

\subsubsection{Soil temperature}

The daily variation in soil temperature of different treatments was measured by curved tube geothermic meter once every $2 \mathrm{~h}$ from 6:00 to 20:00 at $7 \mathrm{~d}, 10 \mathrm{~d}$, and $13 \mathrm{~d}$ after sowing (DAS), respectively. The determination positions were at depths of $0 \mathrm{~cm}$, $5 \mathrm{~cm}, 10 \mathrm{~cm}, 15 \mathrm{~cm}, 20 \mathrm{~cm}$, and $25 \mathrm{~cm}$. The weekly variation in soil temperature of different treatments was measured at 8:00, 14:00, and 20:00, started at 7 DAS, once a week, ended at 56 DAS. 2.3.3 Soil moisture

Soil water content was determined by a neutron meter during
14-70 DAS, once a week, and the soil layers were $0-20 \mathrm{~cm}, 20$ $40 \mathrm{~cm}, 40-60 \mathrm{~cm}, 60-80,80-100 \mathrm{~cm}, 100-120 \mathrm{~cm}, 120-140 \mathrm{~cm}$, and $140-160 \mathrm{~cm}$.

\subsubsection{Maize yield}

At crop maturity, plant samples were taken from each plot to measure the ear characteristics, grain yield (GY) and its components. Ear length, ear diameter, bald tip length, ear row number, row grain number, kernel number per plant (KNP), and 1000-kernel weight (TKW) were determined.

\subsubsection{Statistical analysis}

Variance analysis was performed to determine the effects of degradable films on soil moisture and maize yield using Tukey's HSD test. The notations of $\mathrm{a}$ and $\mathrm{b}$ are used to indicate $\mathrm{a}$ significant difference at $p<0.05$. Statistical analysis was performed using the IBM SPSS Statistics ver. 20.0 (IBM Corporation, Somers, New York) program.

\section{Results}

\subsection{Degradation rates and degrees of degradable films}

As shown in Table 1, DF No. 1 entered the induction period at 30 DAS, reached Level 2 at 50 DAS, Level 3 at 60 DAS, Level 4 at 70 DAS, and Level 5 at 90 DAS, respectively. DF No. 2 entered the induction period at 40 DAS, reached Level 2 at 60 DAS, Level 3 at 70 DAS, and Level 4 at 90 DAS, respectively. DF No. 3 entered the induction period at 50 DAS, reached Level 2 at 60 DAS, Level 3 at 80 DAS, and Level 4 at 90 DAS, respectively. The plastic film with very small cracks appeared at 60 DAS, reached just Level 2 at 90 DAS.

As shown in Table 2, the present weight of $1 \mathrm{~m}$ film in $100 \mathrm{~d}$ for DF No. 1 was $4.04 \mathrm{~g}$, while its original weight $100 \mathrm{~d}$ ago was $5.20 \mathrm{~g}$. The weight was reduced by $1.16 \mathrm{~g}$ with the WLR of $100 \mathrm{~d}$ about $22.31 \%$. The present weight of $1 \mathrm{~m}$ film in $100 \mathrm{~d}$ for DF No. 2 was $3.60 \mathrm{~g}$, while its original weight $100 \mathrm{~d}$ ago was $4.47 \mathrm{~g}$. The 
weight was reduced by $0.87 \mathrm{~g}$ with the WLR of $100 \mathrm{~d}$ about $19.46 \%$. The present weight of $1 \mathrm{~m}$ film in $100 \mathrm{~d}$ for DF No. 3 was $3.40 \mathrm{~g}$, while its original weight $100 \mathrm{~d}$ ago was $4.03 \mathrm{~g}$. The weight was reduced by $0.63 \mathrm{~g}$ with the WLR of $100 \mathrm{~d}$ about $15.63 \%$. The present weight of $1 \mathrm{~m}$ film in $100 \mathrm{~d}$ for the plastic film was $4.24 \mathrm{~g}$, while its original weight $100 \mathrm{~d}$ ago was $4.48 \mathrm{~g}$. The weight was only reduced by $0.24 \mathrm{~g}$ with the WLR of $100 \mathrm{~d}$ about 5.63\%. The WLR of DF No. 1, No. 2 and No. 3 were 4.16, 3.63 , and 2.92 times of the plastic film, respectively.

Table 1 Degradation rates of different films

\begin{tabular}{cccccccccc}
\hline & \multicolumn{8}{c}{ Days after sowing/d } \\
\cline { 2 - 10 } Treatment & 10 & 20 & 30 & 40 & 50 & 60 & 70 & 80 & 90 \\
\hline DF No. 1 & 0 & 0 & 1 & 1 & 2 & 3 & 4 & 4 & 5 \\
DF No. 2 & 0 & 0 & 0 & 1 & 1 & 2 & 3 & 3 & 4 \\
DF No. 3 & 0 & 0 & 0 & 0 & 1 & 2 & 2 & 3 & 4 \\
Plastic film & 0 & 0 & 0 & 0 & 0 & 1 & 1 & 2 & 2 \\
\hline
\end{tabular}

Table 2 Degradation degrees of different films

Original weight of Present weight of Film weight Weight loss Treatment $1 \mathrm{~m}$ film $100 \mathrm{~d}$ ago $1 \mathrm{~m}$ film in $100 \mathrm{~d}$ reduction rate in $100 \mathrm{~d}$

\begin{tabular}{ccccc} 
& $/ \mathrm{g}$ & $/ \mathrm{g}$ & $/ \mathrm{g}$ & $1 \%$ \\
\hline DF No. 1 & 5.20 & 4.04 & 1.16 & 22.31 \\
DF No. 2 & 4.47 & 3.60 & 0.87 & 19.46 \\
DF No. 3 & 4.03 & 3.40 & 0.63 & 15.63 \\
Plastic film & 4.48 & 4.24 & 0.24 & 5.36 \\
\hline
\end{tabular}

\subsection{Effects of degradable films on soil temperature}

The daily variation in soil temperature at 7 DAS, 10 DAS, and 13 DAS were shown in Figures 2-4. As shown in Figure 2, the surface soil temperatures in each treatment had little difference at 7 DAS, increased from 6:00 to reach the highest values at 10:00, then declined to a steady level and kept constant from 14:00. The change of soil temperature in $5 \mathrm{~cm}, 10 \mathrm{~cm}$ and $20 \mathrm{~cm}$ depths were roughly the same as that of the surface soil temperature, but the range of change were smaller and the highest value were reached at 12:00. In $20 \mathrm{~cm}$ and $25 \mathrm{~cm}$ depths, the change of soil temperature was basically the same, and compared with other levels, the daily variation in soil temperature were relatively gentle. The underground soil temperature was higher in film mulching treatments than that of the open ground. As shown in Figure 3, the surface soil temperatures had little difference in each treatment at 10 DAS, increased from 6:00 to 12:00 to reach the highest value, then declined to 18:00 and changed gently from 18:00 to 20:00. The change of soil temperature in $5 \mathrm{~cm}, 10 \mathrm{~cm}$, and $15 \mathrm{~cm}$ depths were roughly the same as that of the surface soil temperature, but the range of change were little and the highest value were reached at 14:00 or 16:00. The underground soil temperatures in film mulching treatments were higher than that of the open ground at 12:00-20:00. As shown in Figure 4, the surface soil temperature at 13 DAS increased from 6:00 to 14:00 to reach the highest value, then declined to 18:00 and changed gently at 18:00 to 20:00. It was also observed that soil temperatures in film mulching treatments were higher than that of the open ground at 8:00-14:00. The soil temperature in $5 \mathrm{~cm}$ and $10 \mathrm{~cm}$ depths were higher in film mulching treatments than that of the open ground at 10:00-20:00, and the soil temperature in $15 \mathrm{~cm}, 20 \mathrm{~cm}$, and $25 \mathrm{~cm}$ depths were higher in film mulching treatments than that of the open ground at 6:00-20:00.

In general, the daily variation in soil temperature in $20 \mathrm{~cm}$ and $25 \mathrm{~cm}$ depths were obviously lower than that in $5 \mathrm{~cm}, 10 \mathrm{~cm}$ and $15 \mathrm{~cm}$ depths, indicating that the soil temperature in $5 \mathrm{~cm}, 10 \mathrm{~cm}$ and $15 \mathrm{~cm}$ depths were greatly influenced by film mulching, while the soil temperature in $20 \mathrm{~cm}$ and $25 \mathrm{~cm}$ depths were less affected. There was little difference in soil temperature under different film mulching, which indicated that 3 degradable films had similar effects on improving and maintaining soil temperature with the plastic film.

The weekly variation in soil temperature at 8:00, 14:00, and 20:00 were shown in Figures 5-7. As shown in Figure 5, the soil temperature at surface or in 5-25 cm depths at 8:00 were higher in film mulching treatments than that of the open ground during 7 56 DAS. The change of soil temperature in $5-25 \mathrm{~cm}$ depths has roughly the same pattern as that of the surface soil temperature, but the range of change was little. As shown in Figure 6, the surface soil temperature at 14:00 appeared a large decline at 35 DAS due to the dramatic drop in air temperature, and the soil temperature in $5 \mathrm{~cm}, 10 \mathrm{~cm}$ and $15 \mathrm{~cm}$ depths changed similarly to the surface, but the variation of temperature gradually decreased with the soil depth increasing. The weekly variation in soil temperature in $20 \mathrm{~cm}$ depths changed similarly to $25 \mathrm{~cm}$ depths, with a small variation range at 14:00 during 7-56 DAS. The soil temperature at surface or in 5-25 cm depths at 14:00 was higher in film mulching treatments than that of the open ground during 7-28 DAS, while the soil temperature in $20-25 \mathrm{~cm}$ depths was higher in film mulching treatments than that of the open ground during 7-56 DAS. As shown in Figure 7, the soil temperature at surface or in 5-25 cm depths at 20:00 appeared a little decline at 35 DAS due to the dramatic drop in air temperature, and the soil temperature was higher in film mulching treatments than that of the open ground during 7-56 DAS, which indicated that 3 degradable films had similar effects on improving and maintaining soil temperature with the plastic film.

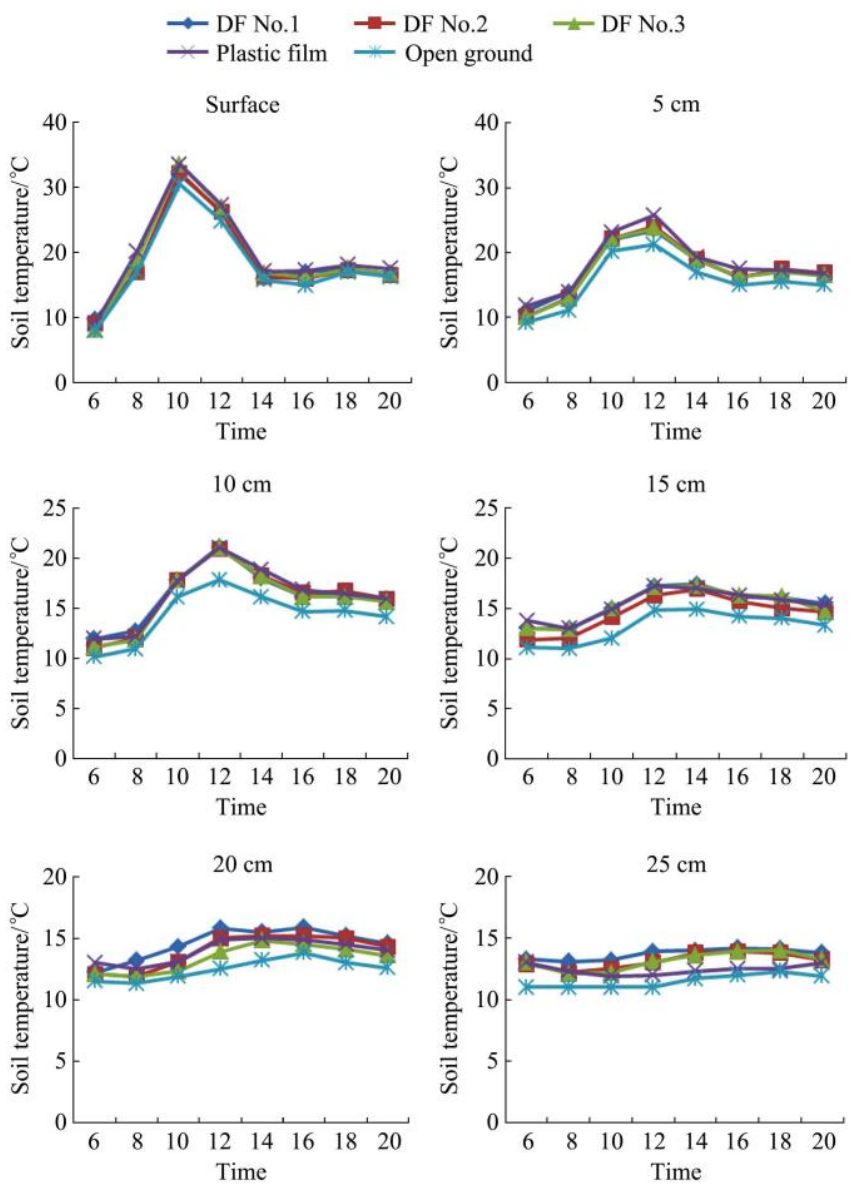

Figure 2 Daily variation in soil temperature at 7 DAS 


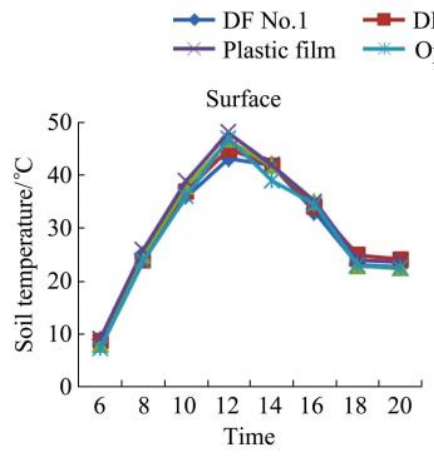

No. $2 \rightarrow$ DF No.3
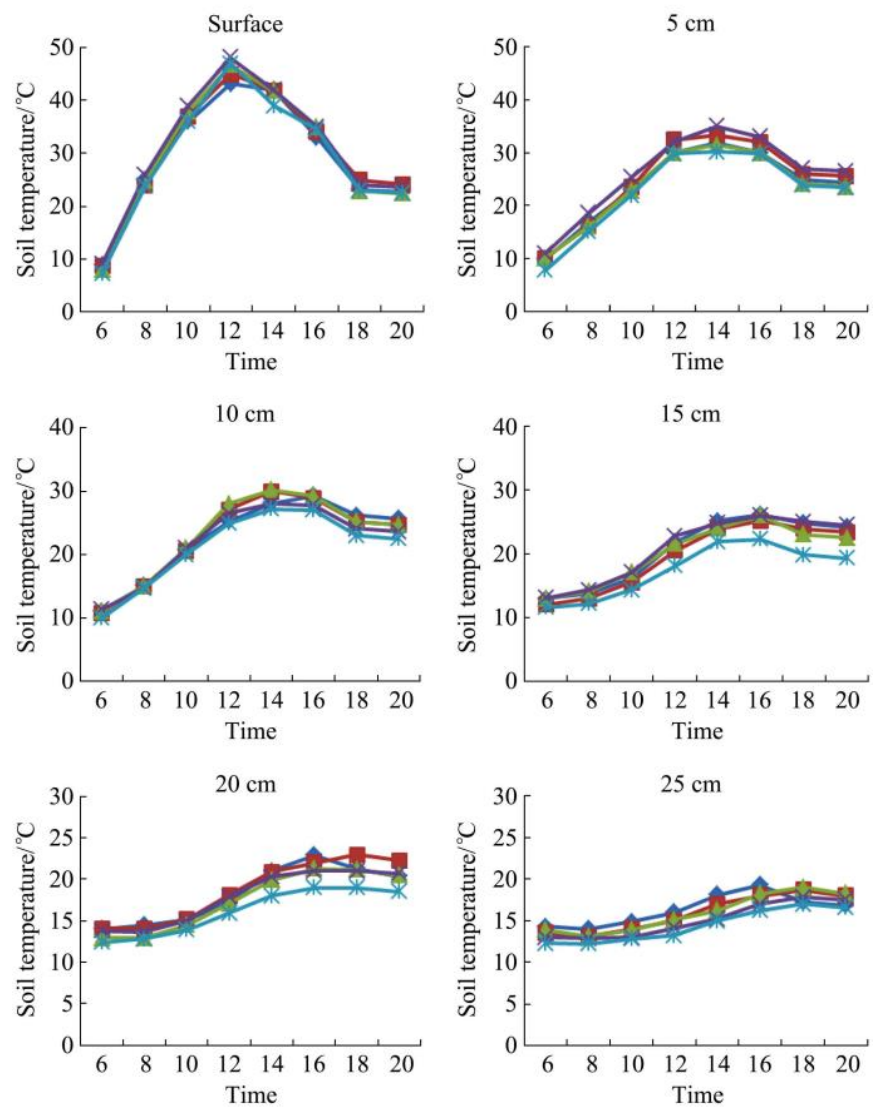

Figure 3 Daily variation in soil temperature at 10 DAS

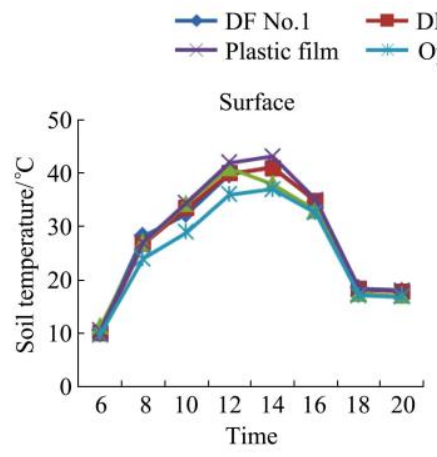

$$
\text { No.2 } \rightarrow \text { DF No.3 }
$$
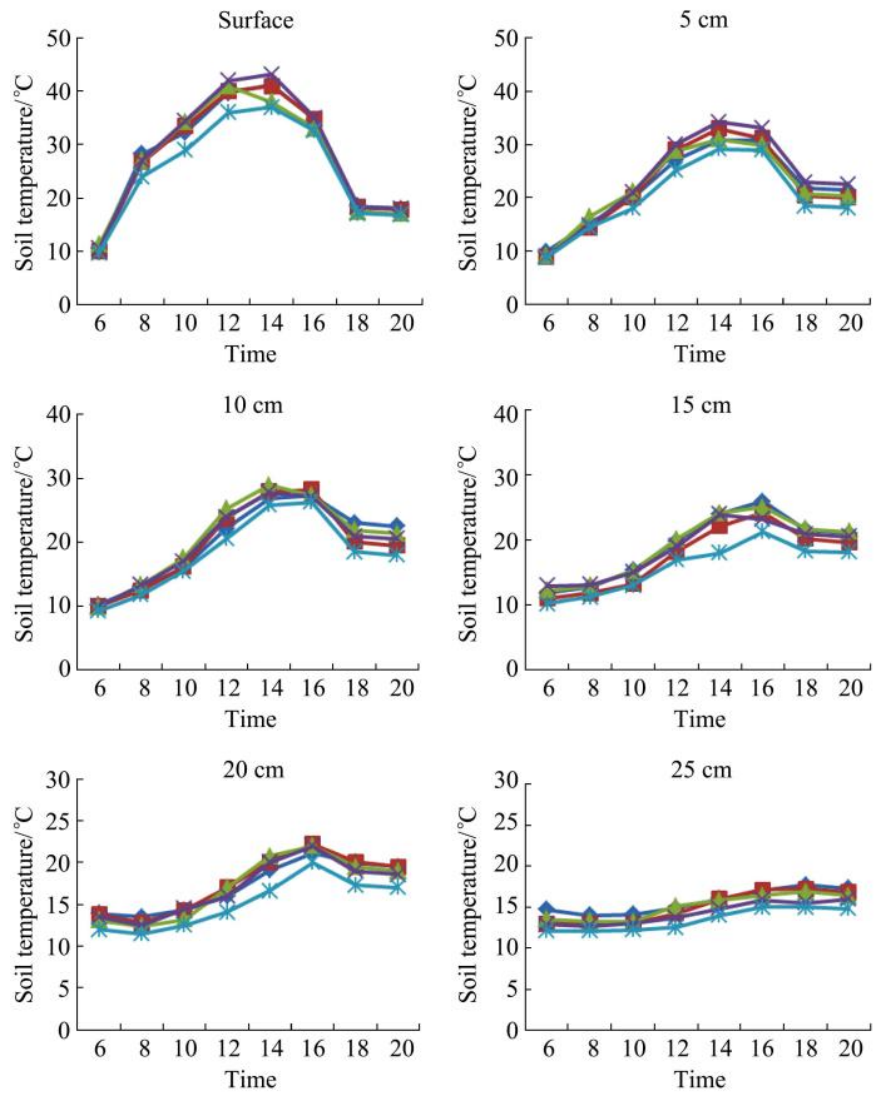

Figure 4 Daily variation in soil temperature at 13 DAS

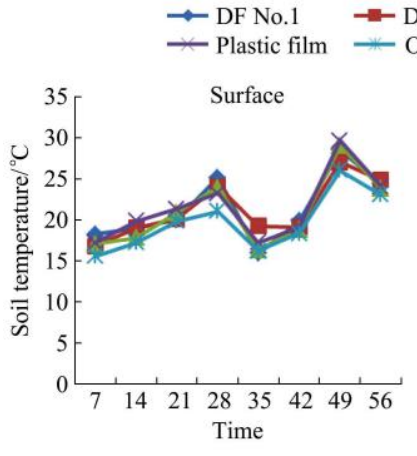

$$
\begin{aligned}
& \text { DF No.2 } \rightarrow \text { DF No.3 } \\
& \text { Open ground }
\end{aligned}
$$
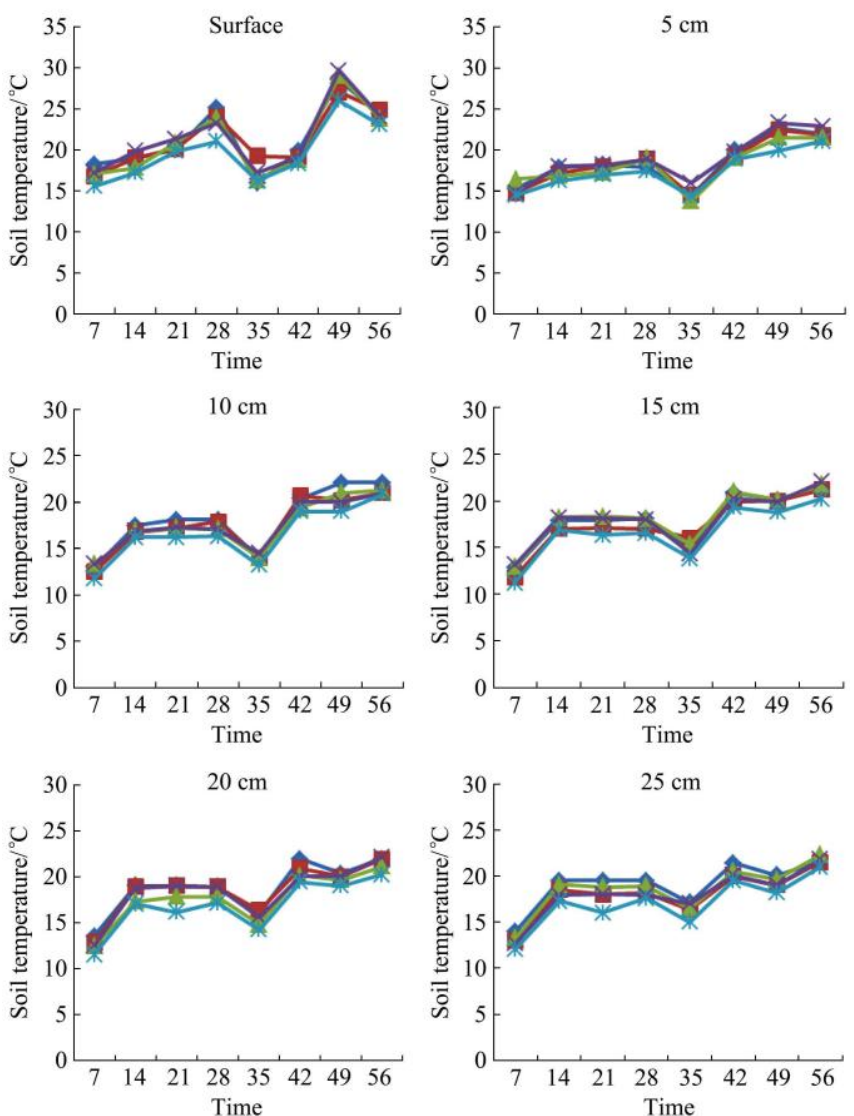

Figure 5 Weekly variation in soil temperature at 8:00

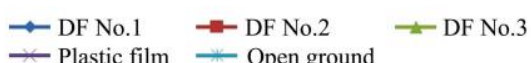
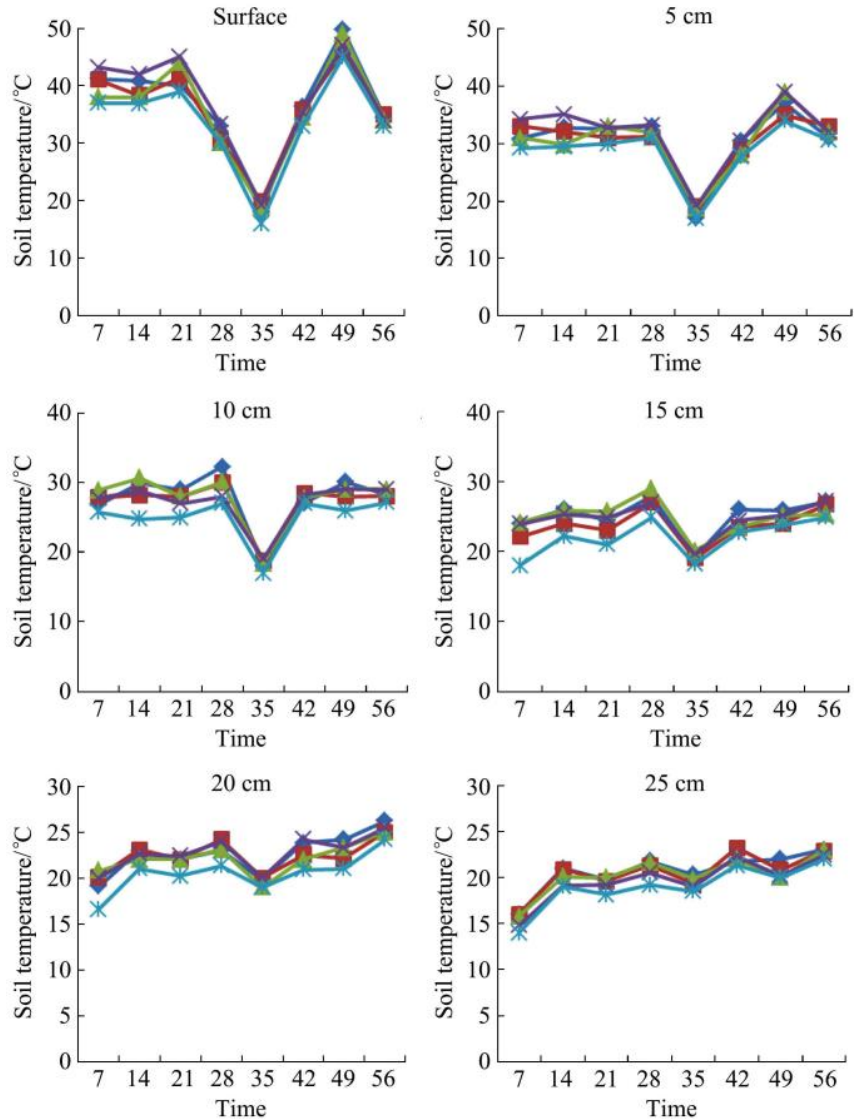

Figure 6 Weekly variation in soil temperature at 14:00 


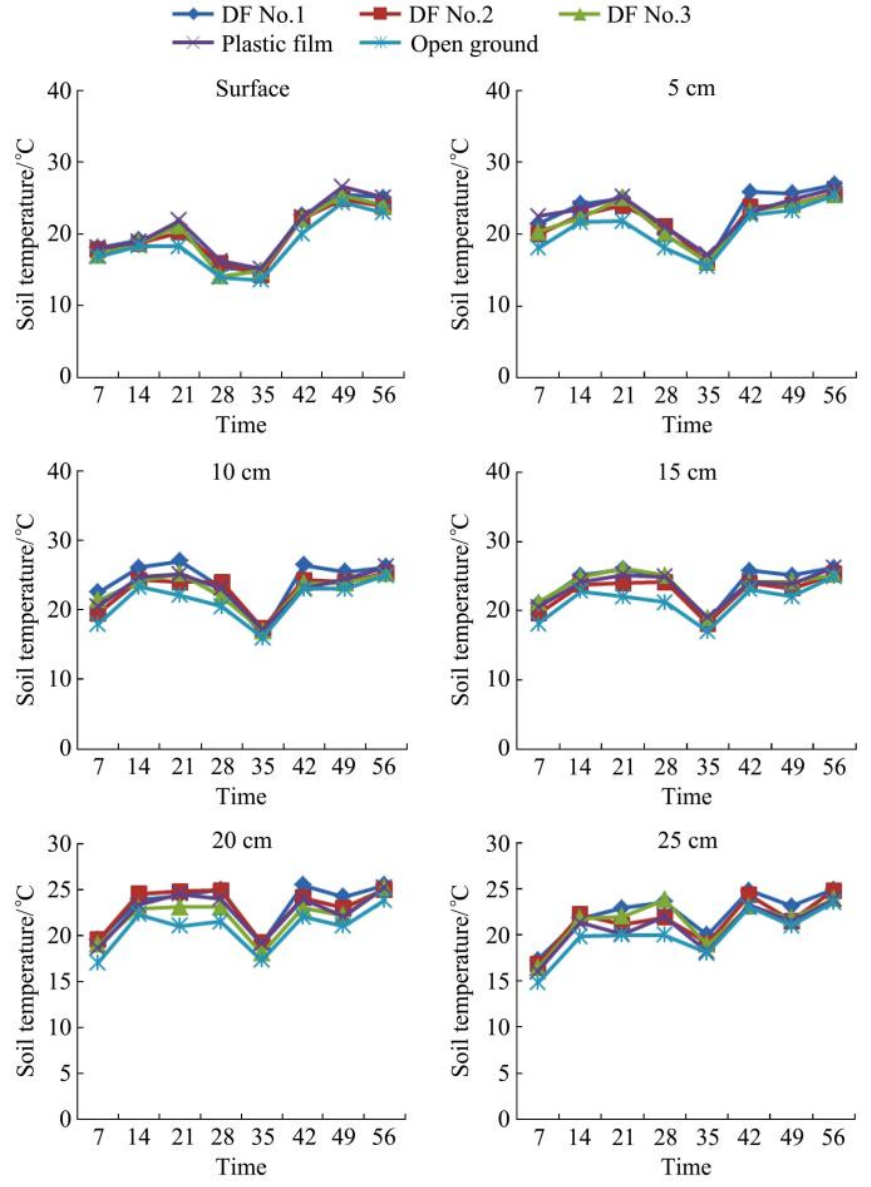

Figure 7 Weekly variation in soil temperature at 20:00

\subsection{Effects of degradable films on soil moisture}

As shown in Figure 8, in 0-20 cm depths, soil under DF No.2 and the plastic film has significantly $(p<0.05)$ higher water content than that of other treatments at 14 DAS, 49 DAS, and 56 DAS, soil under film mulching has significantly higher water content than that of the open ground at 21 DAS, 28 DAS, and 42 DAS, and soil under DF No.2, No.3 and the plastic film has significantly higher water content than that of DF No.1 and the open ground at 35 DAS. In 20-40 cm depths, the soil under DF No.2, No.3 and the plastic film has significantly higher water content than that of DF No.1 and the open ground at 14 and 35 DAS, the soil under DF No.2 and the plastic film has significantly higher water content than that of other treatments at 21 DAS, 49 DAS, and 56 DAS, and the soil under film mulching has significantly higher water content than that of the open ground at 28 DAS and 42 DAS. In $40-60 \mathrm{~cm}$ or $60-80 \mathrm{~cm}$ depths, the soil has no significant difference on water content in each treatment at 14 DAS, the soil under film mulching has significantly higher water content than that of the open ground at 21 DAS, 28 DAS, and 42 DAS, the soil under DF No.2, No.3 and the plastic film has significantly higher water content than that of DF No.1 and the open ground at 35 DAS, and the soil under DF No.2 and the plastic film has significantly higher water content than that of other treatments at 49 DAS. In 40-60 cm depths, the soil water content at 56 DAS were similar to that at 49 DAS. In $60-80 \mathrm{~cm}$ depths, the soil water content at 56 DAS were similar to that at 21 DAS, 28 DAS, and 42 DAS.

As shown in Figure 9, the soil water content in $80-160 \mathrm{~cm}$ depths had no significant $(p<0.05)$ difference in each treatment at 14 DAS. In $80-100 \mathrm{~cm}$ depths, the soil under film mulching has significantly higher water content than that of the open ground at 21 DAS and 56 DAS, the soil under DF No.2, No.3 and the plastic film has significantly higher water content than that of DF No.1 and the open ground at 28 DAS, 35 DAS, and 42 DAS, and the soil under DF No.2 and the plastic film has significantly higher water content than that of other treatments at 49 DAS. In $100-120 \mathrm{~cm}$ depths, the soil under film mulching has significantly higher water content than that of the open ground at 21 DAS, 28 DAS and 56 DAS, the soil under DF No.2 and the plastic film has significantly higher water content than that of other treatments at 35 and 49 DAS, and the soil under DF No.2, No.3 and the plastic film has significantly higher water content than that of DF No.1 and the open ground at 42 DAS. In $120-140 \mathrm{~cm}$ depths, the soil under film mulching has significantly higher water content than that of the open ground at 21 DAS and 56 DAS, the soil under DF No.2, No.3 and the plastic film has significantly higher water content than that of DF No.1 and the open ground at 28 DAS, and the soil under DF No.2 and the plastic film has significantly higher water content than that of other treatments at 35 DAS, 42 DAS and 49 DAS. In 140-160 $\mathrm{cm}$ depths, the soil under film mulching has significant higher water content than that of the open ground at 21 and $28 \mathrm{DAS}$, and no significant difference on water content was observed in each treatment at 35-56 DAS.
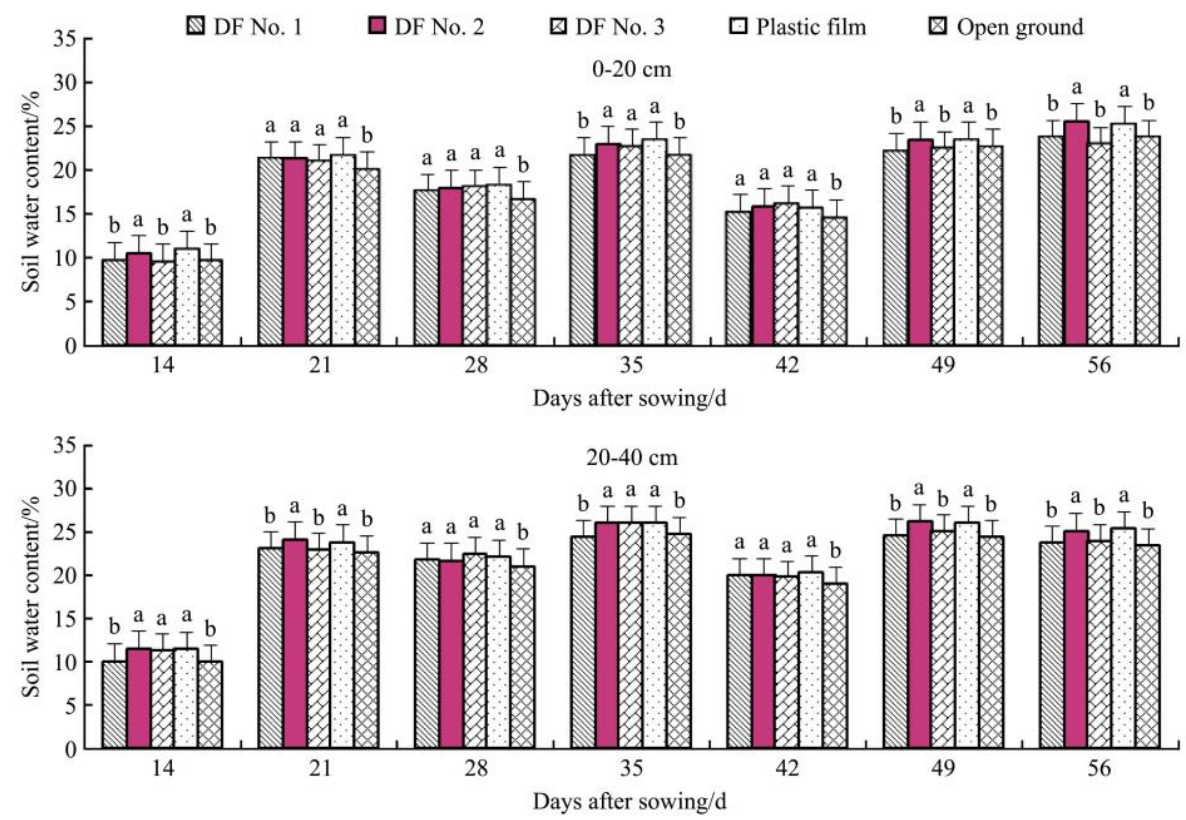

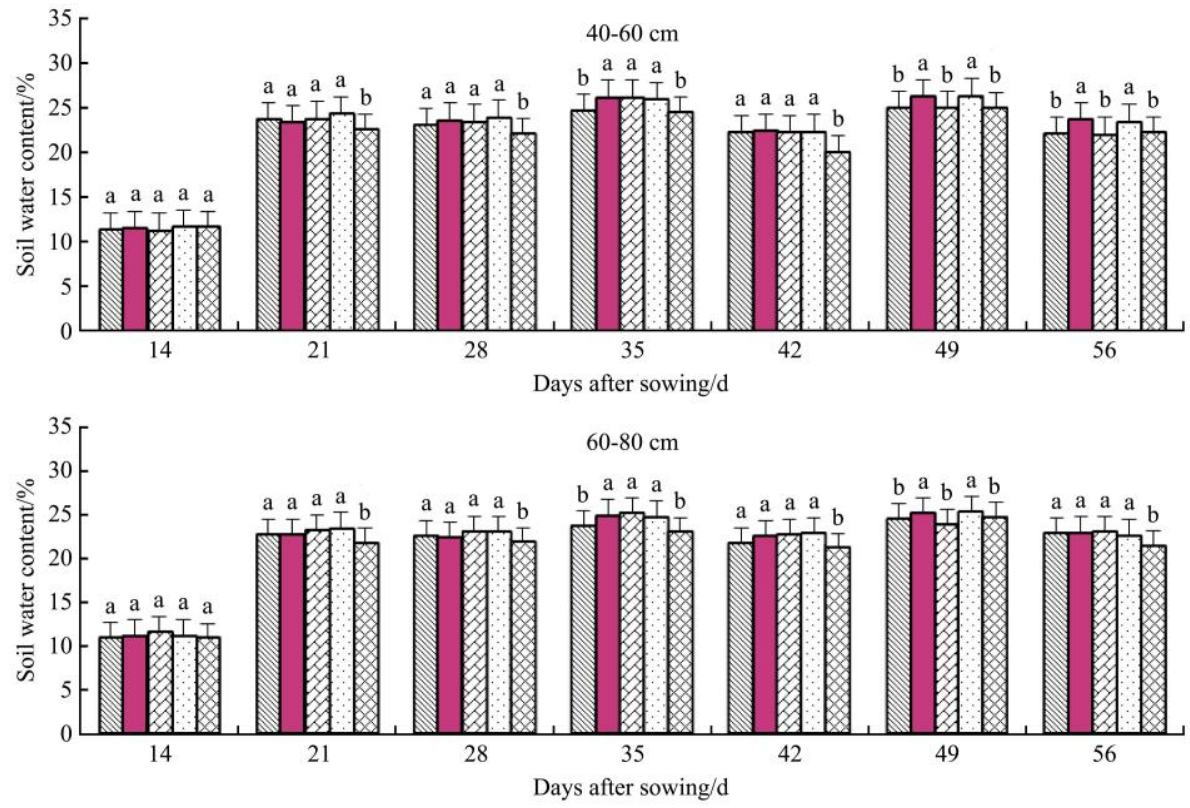

Note: Letters $\mathrm{a}$ and $\mathrm{b}$ indicate significant differences at $p<0.05$ among the treatments, the same as below.

Figure 8 Soil water content in $0-80 \mathrm{~cm}$ depths
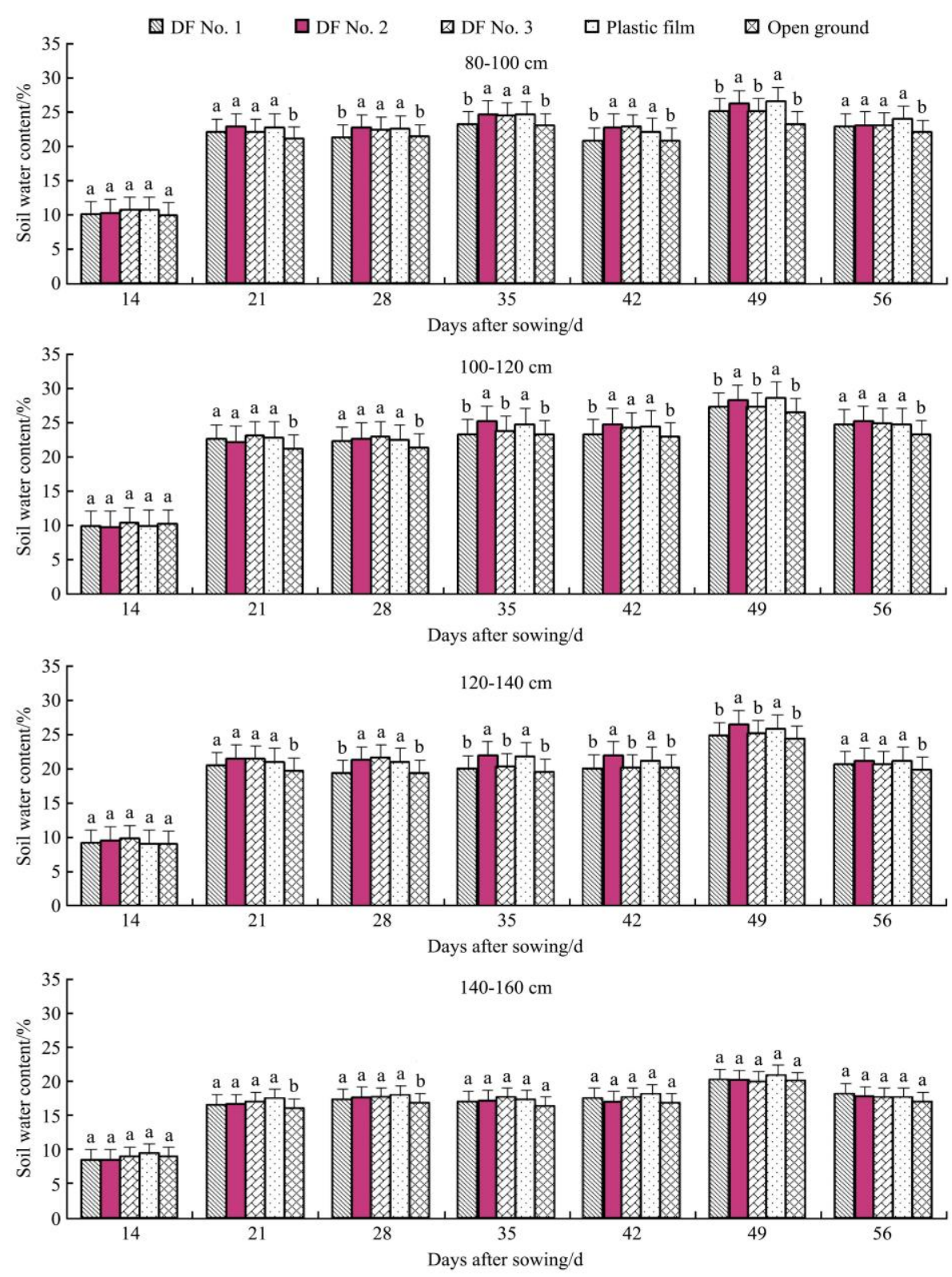

Figure 9 Soil water content in $80-160 \mathrm{~cm}$ depths 
In general, the soil water contents in $0-160 \mathrm{~cm}$ depths were lower at 14 DAS than at other times, and in $40-160 \mathrm{~cm}$ depths the soil water contents had no significant difference in each treatment, but in $0-40 \mathrm{~cm}$ depths the soil under DF No.2 and the plastic film has significantly higher water content than under the open ground. At 21-56 DAS, the soil water content varied in different treatments and different depths, and soil under DF No.2 and the plastic film has similar water content in $0-140 \mathrm{~cm}$ depths, and were significantly higher than that of the open ground.

\subsection{Effects of degradable films on maize grain yields and their components}

Maize grain yields and their components in different treatments are shown in Table 3.For the ear length, no significant differences existed among each treatment. For the ear diameter, the treatments of DF No. 2, No. 3 and the plastic film were significantly $(p<0.05)$ greater than the treatments of DF No. 1 and the open ground. For the bald tip length, the treatments of DF No. 2 , No. 3 and the plastic film were significantly shorter than the treatments of DF No. 1 and the open ground. For KNP, the treatments of film mulching were significantly greater than the open ground while no significant differences existed among the treatments of DF No. 2, No. 3 and the plastic film. For the ear row number, row grain number, TKW and GY, the treatments of film mulching were significantly greater than the open ground. The grain yields (GYs) were improved of $40.06 \%, 35.15 \%, 31.35 \%$, and $30.07 \%$ for the treatments of plastic film, DF No. 2, No. 1 and No. 3 than that for the open ground respectively, with no significant differences among the treatments of film mulching.

Three kinds of degradable films could obviously promote the ear development of maize, improve the ear characteristics, shorten the bald tip, increase KNP and TKW, and increase the final maize GY.

Table 3 Maize grain yields and their components in different treatments

\begin{tabular}{|c|c|c|c|c|c|c|c|c|}
\hline Treatment & $\begin{array}{l}\text { Ear length } \\
/ \mathrm{cm}\end{array}$ & $\begin{array}{c}\text { Ear diameter } \\
/ \mathrm{cm}\end{array}$ & $\begin{array}{l}\text { Bald tip length } \\
/ \mathrm{cm}\end{array}$ & Ear row number & Row grain number & Kernel number & $\begin{array}{l}\text { Kernel weight } \\
\text { /g 1000- } \text { grain }^{-1}\end{array}$ & $\begin{array}{l}\text { Grain yield } \\
/ \mathrm{kg} \cdot \mathrm{hm}^{-2}\end{array}$ \\
\hline DF No. 1 & $22.08 \mathrm{a}$ & $5.14 \mathrm{~b}$ & $1.06 \mathrm{a}$ & $16.0 \mathrm{a}$ & $39.8 \mathrm{a}$ & $636.8 b$ & $331.8 \mathrm{a}$ & $12373.9 \mathrm{a}$ \\
\hline DF No. 3 & $22.16 \mathrm{a}$ & $5.21 \mathrm{a}$ & $0.94 b$ & $16.4 \mathrm{a}$ & $40.3 \mathrm{a}$ & $660.9 \mathrm{a}$ & $319.6 \mathrm{a}$ & $12254.0 \mathrm{a}$ \\
\hline Plastic film & $22.35 \mathrm{a}$ & $5.28 \mathrm{a}$ & $0.97 b$ & $16.8 \mathrm{a}$ & $40.7 \mathrm{a}$ & $683.8 \mathrm{a}$ & $328.5 \mathrm{a}$ & $13194.3 \mathrm{a}$ \\
\hline
\end{tabular}

\section{Discussion}

\subsection{Degradation rates and degrees}

Former researchers had conducted related research on degradable films with different degradability. In 2015, two kinds of biodegradable films provided by KANEKA were tested in China. Results show that the film No. 1 entered the induction period at 21 DAS, which was totally broken at 30 DAS and lost its covering effect as the cracks expanded rapidly, while the film No. 2 entered the induction period at 30 DAS with a relatively longer effective covering time ${ }^{[19]}$. In 2016, 3 kinds of degradable films with different content of degrading masterbatch (Dahua 1, 2, and 3, containing $3 \%, 5 \%$, and $7 \%$ degradation masterbatch, respectively) were tested and the results show that the film of Dahua 3 reached Level 3 at the end of maize growth period, while the film of Dahua 1 and 2 only reached Level 1 and Level 2 respectively ${ }^{[20]}$. The degradation rates and degrees of the degradable films were affected by the content of degrading masterbatch, and in a certain range, higher content of the masterbatch leads to higher degradation rates and higher degrees of the degradable films. In this work, the films of DF No. 1, No. 2, and No. 3 entered the induction period at 30, 40, and 50 DAS respectively, and reached Level 5, Level 4, and Level 4 at 90 DAS respectively. The WLR in $100 \mathrm{~d}$ for DF No. 1 , No. 2 , and No. 3 were $22.31 \%, 19.46 \%$, and $15.63 \%$, which were $4.16,3.63$, and 2.92 times of the plastic film, respectively. The degradation characteristics of degradable films are usually related to their chemical components ${ }^{[21,22]}$, technological parameters, and storage and field environments ${ }^{[23]}$. In the development and production of degradable films, special prodegradant should be added to adjust the physical properties of the films according to the geographical area, cultivation and season ${ }^{[10,24]}$

\subsection{Soil temperature and moisture}

The effects of degradable and conventional plastic films on soil temperature and moisture have been widely documented.
Generally,the degradable film and plastic film have similar effects of increasing soil temperature and moisture at early growth stages ${ }^{[25-29]}$. Biodegradable films warm soils less than polyethylene mulches, which could be favourable in areas and seasons characterized by high temperatures that responsible for damages to the crops, although polyethylene films may be advantageous in areas with cool conditions ${ }^{[30]}$. Wang et al. reported that the average temperature in $0-25 \mathrm{~cm}$ soil of biodegradable film mulching was increased by $1.91^{\circ} \mathrm{C}$ in comparison with the open ground and reduced by $0.85^{\circ} \mathrm{C}$ in comparison with the plastic film mulching, and the water-retention of biodegradable film was $90.4 \%-95.4 \%$ of the plastic film ${ }^{[31]}$. Gu et al. reported that the effects of increasing soil temperature and soil moisture were similar for the biodegradable and plastic film mulching, and were significantly higher than for the open ground before $150 \mathrm{DAS}^{[32]}$. Results from this study got similar conclusion. Previous research indicated that for degradable film mulching, soil temperature at surface and $10 \mathrm{~cm}$ depth and soil moisture in 0-40 cm depths during two months after maize sowing were all obviously higher than the open field, but were little lower than the plastic film mulching ${ }^{[33,34]}$. The present study showed that 3 kinds of degradable films and the plastic film had good warming effects on soil in the early period of maize growth, and the effects of different films were similar. In the early stage of film mulching, soil moisture, especially in deep soil depth, was not affected much. At 14 DAS, the soil water contents in 0-40 cm depths were significantly higher under DF No. 2 and the plastic film than under the open ground, but in $40-160 \mathrm{~cm}$ depths no significant difference between each treatment was observed. At 21-56 DAS, the soil water content varied in different treatments and different depths, and in $0-140 \mathrm{~cm}$ depths, the soil water contents were significantly higher under DF No. 2 and the plastic film than under the open ground $(p<0.05)$. The effect of DF No. 2 mulching on soil moisture was similar with that of the plastic 
film mulching.

\subsection{Grain yield}

Zhang et al. found that compared with the open ground control, GY of maize covered by degradable film and ordinary film were increased by $19.96 \%$ and $19.67 \%$, respectively ${ }^{[27]}$. Hu et al. found that GY of maize covered by biodegradable film were significantly increased $12.63 \%$ and $14.69 \%$ than liquid film and no film treatment, separately ${ }^{[35]}$. Previous research showed that KNP, TKW, and GY of maize under degradable film covering were increased by $9.6 \%, 20.9 \%$, and $35.1 \%$ respectively, and the degradable film did not show significant difference with plastic film ${ }^{[32]}$. In the present study a similar result was gained. For the ear row number, row grain number, KNP, TKW and GY, the treatments of film mulching were significantly greater than the open ground. The GYs for different treatments ranked as the plastic film $>$ DF No. $2>$ DF No. $1>$ DF No. 3>the open ground, which were significantly improved by $40.06 \%, 35.15 \%, 31.35 \%$, and $30.07 \%$ for the plastic film, DF No. 2, DF No. 1, and DF No. 3 respectively than for the open ground $(p<0.05)$. There was no significant difference existing among the film mulching treatments.

\section{Conclusions}

All these three kinds of degradable films had good degradability. DF No. 1, No. 2, and No. 3 entered the induction period at 30 DAS, 40 DAS, and 50 DAS respectively, and reached Level 5, Level 4, and Level 4 at 90 DAS respectively. The WLR in $100 \mathrm{~d}$ for DF No. 1 , No. 2 , and No. 3 were $22.31 \%, 19.46 \%$, and $15.63 \%$, which were $4.16,3.63$, and 2.92 times of the plastic film, respectively.

These three kinds of degradable films had good warming effects on soil in the early period of maize growth, which were similar with the plastic film. The soil water contents in $0-140 \mathrm{~cm}$ depths were significantly higher for DF No. 2 and the plastic film than that for the open ground $(p<0.05)$. The effect of DF No. 2 on soil water conservation, similar with that of the plastic film, was slightly better than that of DF No. 1 or No. 3 .

These three kinds of degradable films could significantly promote the ear development of maize, improve the ear characteristics, shorten the bald tip, and increase KNP and TKW. The GYs for DF No. 2, No. 1, and No. 3 were significantly improved by $35.15 \%, 31.35 \%$, and $30.07 \%$ respectively higher than that for the open ground $(p<0.05)$. The GY was increased more for DF No. 2 than that for DF No. 1 or No. 3, but the difference was not significant. With no significant difference in GY between DF and the plastic film, 3 kinds of degradable films successfully fulfilled all the functions of the plastic film, thus were recommended as viable option to the plastic film due to their good degradability.

\section{Acknowledgements}

This work was financially supported by the National Natural Science Foundation of China (31271645), the Agricultural Science and Technology Project (20140311007-4), the Natural Science Foundation (201701D121109), and the Key research and development plan (201703D211020-2) of Shanxi Province, China.

\section{[References]}

[1] Dong H Z, Li W J, Tang W, Zhang D M. Early plastic mulching increases stand establishment and lint yield of cotton in saline fields. Field Crops Research. 2009; 111(3): 269-275.

[2] Calatrava J, Franco J A. Using pruning residues as mulch: analysis of its adoption and process of diffusion in Southern Spain olive orchards. Journal of Environmental Management, 2011; 92(3): 620-629.

[3] Nawaz A, Lal R, Shrestha R K, Farooq M. Mulching affects soil properties and greenhouse gas emissions under long-term no-till and plough-till systems in Alfisol of Central Ohio. Land Degradation and Development, 2016; 28(2): 673-681.

[4] Nishigaki T, Shibata M, Sugihara S, Mvondo-Ze A D, Araki S, Funakawa $\mathrm{S}$. Effect of mulching with vegetative residues on soil water erosion and water balance in an oxisol cropped by cassava in east cameroon. Land Degradation and Development, 2016; 28(2): 682-690.

[5] Liu Y, Yang H, Li Y, Yan H, Li J. Modeling the effects of plastic film mulching on irrigated maize yield and water use efficiency in sub-humid Northeast China. Int J Agric \& Biol Eng, 2017; 10(5): 69-84.

[6] Liu C A, Jin S L, Zhou L M, Jia Y, Li F M, et al. Effects of plastic film mulch and tillage on maize productivity and soil parameters. European Journal of Agronomy, 2009; 31(4): 241-249.

[7] Li R, Hou X, Jia Z, Han Q, Ren X, Yang B. Effects on soil temperature, moisture, and maize yield of cultivation with ridge and furrow mulching in the rainfed area of the loess plateau, China. Agricultural Water Management, 2013; 116(1): 101-109.

[8] Ren X, Chen X, Cai T, Wei T, Wu Y, Ali S, et al. Effects of ridge-furrow system combined with different degradable mulching materials on soil water conservation and crop production in semi-humid areas of China. Frontiers in Plant Science, 2017; 8: 1877

[9] Li C, Moore-Kucera J, Lee J, Corbin A, Brodhagen M, Miles C, et al. Effects of biodegradable mulch on soil quality. Applied Soil Ecology, 2014 79(1): 59-69.

[10] Briassoulis D. Mechanical behaviour of biodegradable agricultural films under real field conditions. Polymer Degradation and Stability, 2006; 91(6): 1256-1272

[11] Scarascia-Mugnozza G, Schettini E, Vox G, Malinconico M, Immirzi B, Pagliara S. Mechanical properties decay and morphological behaviour of biodegradable films for agricultural mulching in real scale experiment. Polymer Degradation and Stability, 2006; 91(11): 2801-2808.

[12] Ren X. Biodegradable plastics: a solution or a challenge. Journal of Cleaner Production, 2003; 11(1): 27-40.

[13] Gao Y, Xie Y, Jiang H, Wu B, Niu J. Soil water status and root distribution across the rooting zone in maize with plastic film mulching. Field Crops Research. 2014; 156(2): 40-47.

[14] Yang N, Sun Z X, Feng L S, Zheng M Z, Chi D C, Meng W Z, et al Plastic film mulching for water-efficient agricultural applications and degradable films materials development research. Materials and Manufacturing Processes, 2014; 30(2): 143-154.

[15] Kader M A, Senge M, Mojid M A, Ito K. Recent advances in mulching materials and methods for modifying soil environment. Soil and Tillage Research, 2017; 168(5): 155-166.

[16] Moreno M M, Gonzálezmora S, Villena J, Campos J A, Moreno C. Deterioration pattern of six biodegradable, potentially low-environmental impact mulches in field conditions. Journal of Environmental Management, 2017; 200: 490.

[17] Haapala T, Palonen P, Korpela A, Ahokas J. Feasibility of paper mulches in crop production: A review. Agricultural and Food Science, 2014; 23(1) 60-79.

[18] Braunack M V, Johnston D B, Price J, Gauthier E. Soil temperature and soil water potential under thin oxodegradable plastic film impact on cotton crop establishment and yield. Field Crops Research, 2015; 184: 91-103.

[19] Meng Z L, Liu Z Y, Yang Y T, Wang Z, Chen D S, Gao L H. Evaluation of the applicability of two kinds of degradable film. Agricultural Engineering Technology, 2015; 28: 42-45. (in Chinese)

[20] He Z G, Dai H Y. Degradation performance of degradable film and its effect on soil temperature, moisture, growth and yield of maize. Water Saving Irrigation, 2016; 4: 41-43. (in Chinese)

[21] Choa J W, Chun B C, Park J S. Ultraviolet reflective and mechanical properties of polyethylene mulching films. European Polymer Journal, 2001; 37(6): 1227-1232.

[22] Willett J L. Mechanical properties of LDPE/granular starch composites. Journal of Applied Polymer Science, 2010; 54(11): 1685-1695.

[23] Lawton J W. Effect of starch type on the properties of starch containing films. Carbohydrate Polymers, 1996; 29(3): 203-208.

[24] Kijchavengkul T, Auras R, Rubino M, Ngouajio M, Fernandez R. Assessment of aliphatic -aromatic copolyester biodegradable mulch films. Part I : Field study. Chemosphere, 2008; 71: 942-953.

[25] Kyrikou I, Briassoulis D. Biodegradation of agricultural plastic films: A 
critical review. Journal of Polymers and the Environment, 2007; 15(3): 227-227

[26] Subrahmaniyan K, Zhou W. Soil temperature associated with degradable, non-degradable plastic and organic mulches and their effect on biomass production, enzyme activities and seed yield of winter rapeseed. Journal of Sustainable Agriculture, 2008; 32(4): 611-627.

[27] Waterer D. Evaluation of biodegradable mulches for production of warm-season vegetable crops. Canadian Journal of Plant Science, 2010; 90(5): 737-743

[28] Costa R, Saraiva A, Carvalho L, Duarte E. The use of biodegradable mulch films on strawberry crop in Portugal. Scientia Horticulturae, 2014; 173: 65-70.

[29] Luvisi A, Panattoni A, Materazzi A. RFID temperature sensors for monitoring soil solarization with biodegradable films. Computers \& Electronics in Agriculture, 2016; 123: 135-141.

[30] Moreno M M, Moreno A. Effect of different biodegradable and polyethylene mulches on soil properties and production in a tomato crop.
Scientia Horticulturae, 2008; 116(3): 256-263.

[31] Wang S Y, Fan T L, Li S Z, Zhang J J, Zhao G, WANG L, et al. Property of biodegradable film degradation, water-retention and increasing soft temperature and its impact on maize growth and development process. Agricultural Research in the Arid Areas, 2016; 34(1): 127-133. (in Chinese)

[32] Gu X B, Li Y N, Du Y D. Biodegradable film mulching improves soil temperature, moisture and seed yield of winter oilseed rape (Brassica napus L). Soil and Tillage Research, 2017; 171: 42-50.

[33] Shen L X, Wang P, Zhang L L. Degradation of degradable film and its effect on soil temperature and moisture and maize growth. Transactions of the CSAE, 2012; 28(1): 111-116. (in Chinese)

[34] Shen L X, Wang P, Zhang L L. Effects of degradable film on soil temperature, moisture and growth of maize. Trans of the CSAE, 2011; 27(6): 25-30. (in Chinese)

[35] Hu M, Miao Q F, Shi H B, Yu Q F. Effects of different film mulching on growth traits and water use efficiency for spring maize. Journal of Arid Land Resources and Environment.2017; 31(2): 173-177. (in Chinese) 